\title{
Pelanggaran Kedaulatan Indonesia oleh \\ Pesawat F-18 Hornet Milik Amerika Serikat (Ditinjau Dari Konvensi Chicago Tahun 1944 Dan Konvensi Hukum Laut Tahun 1982)
}

\author{
Gerald Alditya Bunga \\ Faculty of Law, University of Nusa Cendana, Indonesia \\ gerald.bunga@yahoo.com
}

Submitted: 2017-02-17; Reviewed: 2017-05-05; Accepted: 2017-06-06

\begin{abstract}
The sovereignty is the highest attribute of a state that should be respected by another states. In any situation it must not be violated by others but the result of this research shows that F-18 Hornet air craft is state air craft has done a sovereignty collision over Indonesian air space with fly without permission of Indonesian government and made some manuver in civil flight line that endangered the safety of navigation of civil air craft aviation. This reserch also shows that the military strenght of USA is bigger than Indonesian's, influence the sovereignty colission over Indonesian air space, made by F-18 Hornet. Therefore in the international relationship between states, then diplomatic settlement is the best way to choose. Beside that, it is important to determine the limit between air space and outer space, then coul be knew how far the souvereingty of a state over air space.
\end{abstract}

Keywords: air craft; air law; sovereignty

\section{PENDAHULUAN}

Salah satu wujud nyata dari kedaulatan suatu negara adalah wilayah dari negara itu sendiri. Dalam lingkup wilayah tersebut negara memiliki kewenangan untuk melakukan tindakan-tindakan menyangkut kepentingannya dalam wilayah tersebut. Dalam lingkungan yang dibatasi oleh garis-garis perbatasan tersebut, negara merupakan pemegang kedaulatan tertinggi yang berhak mengatur segala sesuatu yang berada dalam wilayahnya.
Kedaulatan merupakan salah satu prinsip dasar bagi terciptanya hubungan internasional yang damai. Yang dimaksud dengan kedaulatan atas wilayah adalah kewenangan yang dimiliki suatu negara untuk melaksanakan kewenangannya sebatas dalam wilayah-wilayah yang telah menjadi bagian dari kekuasaannya. ${ }^{1}$ Bagi suatu negara, wilayahnya terdiri dari wilayah darat, wilayah laut dan wilayah udara. Seperti halnya wilayah darat dan

\footnotetext{
1 Thontowi. J. dan Iskandar. P, Hukum Internasional Kontemporer, Bandung: Refika Aditama, 2006, hlm. 169
} 
laut, wilayah udara juga mempunyai arti yang penting. Ruang udara penting untuk: ${ }^{2}$

1. Menjamin keselamatan penerbangan;

2. Salah satu sumber pendapatan negara;

3. Melindungi warga negara dari serangan negara lain;

4. Sarana nilai tawar dalam perjanjian internasional.

Sebelum Konvensi Paris Tahun 1919 dan Konvensi Chicago Tahun 1944, mengenai ruang udara yang berada di atas wilayah suatu negara yang berdaulat, belum ada suatu aturan yang menetapkan bahwa ruang udara tersebut tunduk pada kedaulatan negara tersebut. Kemudian setelah ditetapkannya Konvensi Paris Tahun 1919 dan kemudian diikuti dengan Konvensi Chicago Tahun 1944 maka diakui bahwa ruang udara yang berada di atas wilyah suatu negara, tunduk pada kedaulatan negara tersebut.

Dalam Pasal 1 konvensi Chicago Tahun 1944 Tentang Penerbangan Sipil Internasional dikatakan bahwa setiap negara memiliki kedaulatan yang lengkap dan eksklusif terhadap ruang udara di atas wilayahnya. Oleh karena itu maka negara lain harus menghormati kedaulatan suatu negara atas ruang udara yang dikuasainya. Sikap hormat itu dapat ditunjukan misalnya dengan meminta izin dari negara yang bersangkutan sebelum melintas melalui wilayah udaranya. Kedaulatan negara atas ruang udara ini juga dicantumkan dalam konvensi Hukum Laut Tahun 1982 pasal 2 dan khusus mengenai

\footnotetext{
2 Martono. H. K, Kamus Hukum Dan Regulasi Penerbangan, Edisi Pertama, Jakarta: Raja Grafindo2007, hlm. 281
}

kedaulatan atas ruang udara di atas perairan kepulauan dicantumkan dalam Pasal 49 ayat (2). Selanjutnya dalam pasal 3 butir d ditegaskan bahwa penerbangan pesawat udara negara tidak boleh mengganggu keamanan navigasi penerbangan pesawat sipil. Hal ini sangat erat kaitannya dengan keselamatan penerbangan.Namun pada tanggal 3 juli 2003, empat pesawat F-18 Hornet milik angkatan Laut Amerika Serikat telah melakukan penerbangan tanpa izin di atas laut Jawa, sebelah barat Pulau Bawean.

Pesawat F-18 Hornet yang merupakan pesawat udara negara ini, bahkan sempat melakukan manuver dalam jalur penerbangan sipil Green 63 dekat Pulau Bawean atau 66 mil laut dari Surabaya. Manuver mereka mengganggu lalu lintas penerbangan sipil yang menggunakan jalur tersebut dan terlihat visual oleh awak kokpit pesawat boeing 737 - 200 Bouraq yang tengah menuju Surabaya. Apa yang telah dilakukan oleh Pesawat F-18 Hornet tersebut jelas telah melanggar ketentuan yang telah diatur dalam Konvensi Chicago Tahun 1944. Dengan penelitian ini maka akan diketahui mengenai bagaimana pelanggaran kedaulatan wilayah yang telah dilakukan oleh pesawat F-18 Hornet milik Amerika Serikat ditinjau Konvensi Chicago dan Konvensi Hukum Laut

\section{PEMBAHASAN}

\section{Kasus Posisi}

Selama tiga menit, hari Kamis 3 Juli 2003, sempat terjadi perang elektronika di atas Laut Jawa, sebelah barat laut Pulau Bawean, antara pesawat tempur supersonik mesin tunggal F-16 Fighting Falcon TNI AU dengan jet tempur supersonik bermesin ganda F-18 Hornet 
Angkatan Laut Amerika Serikat. Pada saat bersamaan, Hornet terus-menerus mengunci (lock) sasaran pesawat F-16 dengan peluru kendali yang siap setiap detik ditembakkan ke sasarannya.

Pesawat F-18 Hornet bersikap bermusuhan (hostile) saat berjumpa di atas perairan Bawean dengan dua peswat F-16 Indonesian Air Force (IAF) Pangkalan Udara Madiun, Jawa Timur. Hari itu kedua pesawat IAF mendapat tugas untuk mengidentifikasi empat pesawat tak dikenal yang bermanuver dalam jalur penerbangan sipil Green 63 dekat Pulau Bawean atau sekitar 66 mil laut dari Surabaya. Manuver mereka mengganggu lalu lintas penerbangan komersial yang menggunakan jalur tersebut dan terlihat visual oleh awak kokpit pesawat Boeing 737-200 Bouraq yang tengah menuju Surabaya.

TNI AU melancarkan aksi jamming radar pesawat IAF. Namun, para penerbang pesawat F-16 mampu mengatasi perang Electronic Counter Measure (ECM) yang dilancarkan pesawat F-18 Hornet. Kedua pesawat F-16 mengatasinya dengan menghidupkan perangkat anti-jamming kemudian memasang alatnya pada mode otomatis sehingga usaha untuk menutup "mata" pesawat F-16 tidak berhasil dilakukan pesawat F-18 Hornet.

Guna menghindari dari peluru kendali yang bakal dilepas pesawat F-18 Hornet, awak pesawat F-16 melakukan beberapa manuver penghindar, antara lain hard break ke kiri dan ke kanan atau zigzagging yang awaknya sampai terkena efek $9 \mathrm{~g}$ atau sembilan kali gravitasi tarikan Bumi. Manuver ini adalah gerakan yang bisa melepaskan diri dari lock peluru kendali. Pada saat itu posisi pesawat F-16 berada pada posisi menguntungkan, bisa pula (kalau mau) menembak mereka,. Namun karena tugas kedua F-16 adalah misi identifikasi, mereka tidak menunjukkan sikap bermusuhan terhadap kedua F-18 Hornet. Sikap bermusuhan kedua pesawat F-18 Hornet memudar setelah Kapten Tonny dan Kapten Satriyo melakukan manuver rocking the wing (menggerak-gerakan sayap) F-16 bernomor ekor TS-1602, isyarat internasional bahwa pesawat F-16 bernomor ekor TS-1603 yang diawaki Kapten Ian dan Kapten Fajar tidak mengancam.

Pangkalan Udara Iswahjudi yang hanya terletak sekitar 20 menit penerbangan diperintahkan Panglima Komando Sektor Pertahanan Udara Nasional II Marsekal Muda Teddy Sumarno untuk mengirim pesawat F-16 ke lokasi, antara lain karena ada keluhan dari pesawat Bouraq Indonesia Airlines dan Mandala Airlines yang merasa terganggu atas manuver (latihan) yang dilakukan oleh sedikitnya lima pesawat F-18 Hornet. Jet tempur tersebut berasal dari kapal induk bertenaga nuklir, USS Carl Vinson, yakni super-carrier kelas Nimitz yang sedang berlayar dari arah barat ke timur bersama dua fregat dan sebuah kapal perusak Angkatan Laut Amerika Serikat. Kapal induk kelas Nimitz mengangkut 100 pesawat tempur, 16 pesawat pengintai, dan enam helikopter, diawaki oleh 3.184 kelasi dan perwira, 2.800 pilot dan awak pendukungnya, serta 70 personel lainnya. Kapal induk ini juga memiliki kemampuan melakukan perang elektronika.

Menurut para penerbang pesawat F-16, kontak visual mereka dengan pesawat F- 
18 Hornet terjadi pada ketinggian 15.000 kaki setelah terbang sekitar 10 menit. Pada jarak di bawah 40 mil laut, radar pesawat F-16 sudah menangkap target pesawat F18 sehingga kedua pesawat TNI AU tersebut langsung menuju ke sasaran terdekat dibantu oleh Surabaya Director (Bandar udara Juanda).

Perang elektronika, seperti dituturkan oleh Kapten Ian Fuady, berhenti setelah F16 yang diawaki Kapten Tonny-Kapten Satriyo melakukan gerakan rocking the wing. "Hornet, Hornet, we are Indonesian Air Force...," terdengar suara Kapten Ian Fuady dalam rekaman radar ulangan yang ditayangkan gambarnya di Lanud Iswahjudi. "Indonesian Air Force... we are in international waters, please stay away from our ships...," terdengar jawaban dari salah satu pilot F-18 Hornet. Penerbang F16 menjawab bahwa kedua Fighting Falcon sedang melakukan patroli dan akan menjauh dari iringan konvoi kapal perang Angkatan Laut AS.

Di markas Makasar, Marsekal Muda Teddy Sumarno terus mengikuti jalan operasi identifikasi kedua F-16 yang diperintahkan menuju lokasi Bawean. "Kami memperkirakan, konvoi kapalkapal AS dengan kecepatan 20 knot akan sampai di sekitar Pulau Madura dan Kangean 12 jam kemudian. Tepat seperti dugaan Jumat 4 Juli pagi kemarin, kami kirim pesawat intai Boeing 737 ke daerah itu dan benar pada pukul tujuh pagi pesawat pengintai menjumpai iringan kapal induk, sebuah kapal perusak dan dua kapal fregat menuju ke Selat Lombok," ungkapnya.

Menurut Marsma Teddy Sumarno, ketika Boeing 737 menanyakan dari mana dan ke mana tujuan mereka, hanya mendapat jawaban: "We are in international waters..." Dalam pengintai ini, Boeing 737 TNI AU sempat memotret kapal induk USS Carl Vinson, kedua fregat, dan kapal perusak AS yang dikawal pesawat-pesawat Hornet tersebut.

Dari kasus posisi yang dipaparkan di atas maka Pelanggaran-pelanggaran yang dilakukan pesawat F-18 Hornet Angkatan Laut Amerika Serikat :

1. Pesawat F-18 Hornet tidak melapor ke menara pengawas bandar udara Juanda (Surabaya Director), padahal mereka menggunakan jalur penerbangan komersil. Dalam aturan internasional, pesawat apapun yang menggunakan jalur ini harus melapor ke menara pengawas. Laporan ini berkaitan erat dengan keselamatan penerbangan yang dituangkan dalam peraturan internasional, International Civil Aviation Organisation (ICAO).

2. Pesawat F-18 Hornet melakukan manuver di jalur penerbangan komersil Green 63 dekat Pulau Bawean atau 66 mil laut dari Surabaya. Manuver itu menggangu lalu lintas penerbangan komersial yang menggunakan jalur tersebut dan terlihat oleh awak kokpit Pesawat Boeing 737-200 Bouraq yang tengah menuju Surabaya. Padahal dalam aturan internasional, jalur penrbangan komersial tidak boleh dipakai untuk menuver provokatif, apalagi sampai membahayakan pesawat lain.

3. Pesawat F-18 Hornet menunjukan sikap bermusuhan (Hostile) 
terhadap Pesawat F-16 TNI AU dari Indonesian Air Forces (IAF), Pangkalan udara Madiun, Jawa Timur. Hal ini ditunjukan dengan terus-menerus mengunci (lock) sasaran F-16 dengan peluru kendali yang setiap detik siap ditembakan ke sasarannya. Yang kedua mereka melaksanakan aksi jamming radar pesawat F-16. sikap bermusuhan ini tidak pantas ditunjukan oleh mereka, karena pesawat IAF hanya ditugasi untuk melakukan intersepsi guna mencari data pesawat apa jenisnya, dari negara mana, dan apa tujuan mereka melaksanakan latihan. ${ }^{3}$

Dalam hukum internasional, Negara sebagai subyek hukum internasional memiliki kedaulatan di wilayahnya yang disebut kedaulatan wilayah (territorial sovereignty). Dalam konsep kedaulatan wilayah, Negara mempunyai hak eksklusif atas wilayahnya. Negara dapat menentukan hukum yang berlaku, mewajibkan orang atau barang yang masuk dari Negara lain untuk mendapat izin, melarang kapal laut atau pesawat udara berbendera asing untuk memasuki wilayahnya dan masih banyak lagi.
Berkaitan dengan pelanggaran kedaulatan wilayah ruang udara Negara indonesia yang dilakukan oleh pesawat F-18 Hornet milik Amerika Serikat, maka acuan pertama yang digunakan untuk melakukan analisis adalah Konvensi Chicago Tahun 1944 Tentang Penerbangan Sipil Internasional. Selanjutnya akan dianlisis juga Berdasarkan Konvensi Hukum Laut Tahun 1982 dan melihat pengaruh besarnya kekuatan militer suatu terhadap terjadinya kasus ini. Untuk mendapat gambaran yang lebih jelas mengenai lokasi terjadinya peristiwa ini, maka dapat dilihat pada gambar di bawah ini.

${ }^{3}$ http://www.angkasaonline.com/13/11/horizon/hori zon1.htm. 


\section{Gambar 1. Lokasi Penerbangan Peswat F-18 Hornet di Dekat Pulau Bawean}

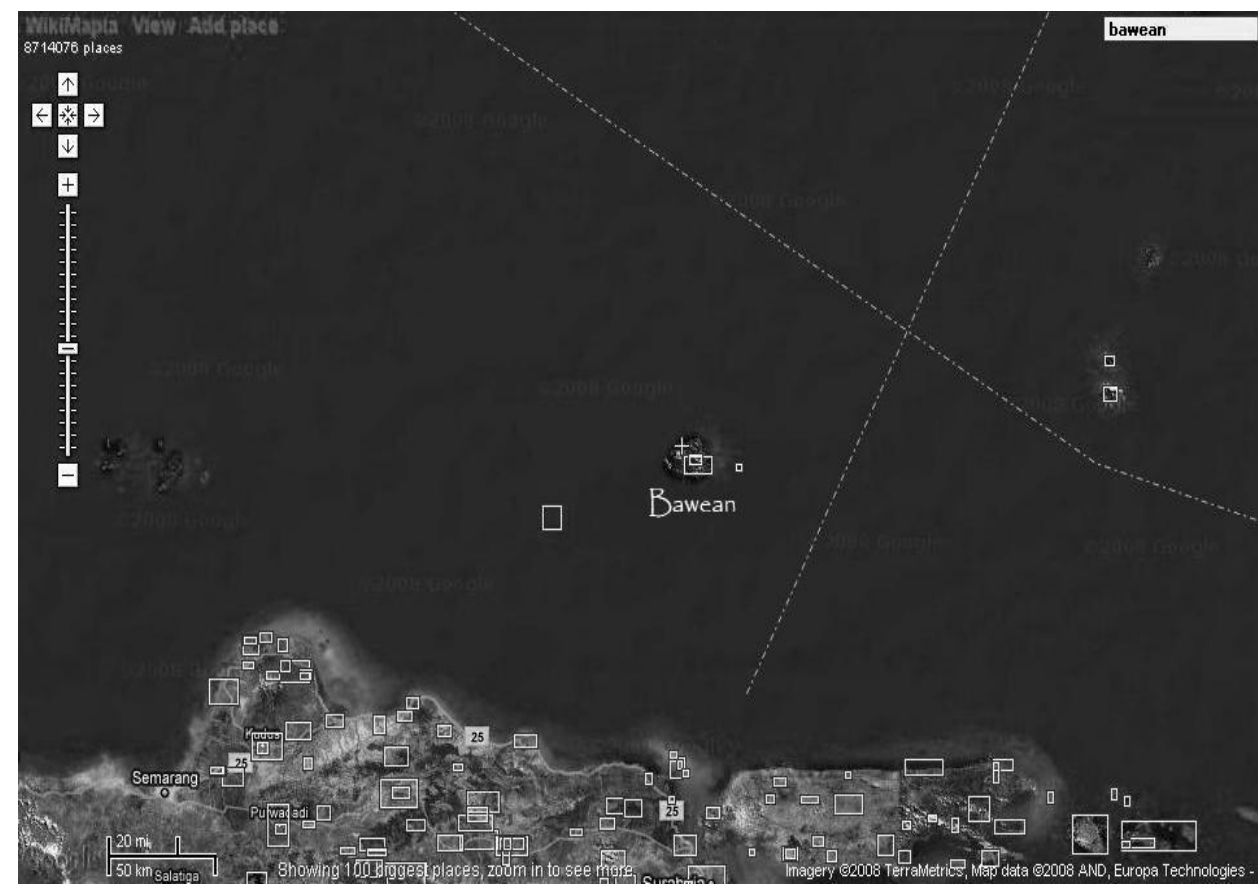

Sumber: Http//:www.Zeal-of-zhull.blog.friendster.com

Keterangan : X : Lokasi penerbangan pesawat F-18 Hornet

Tinjauan Berdasarkan Hukum Udara

Batas Kedaulatan Negara di Ruang Udara

Dalam Konvensi Chicago Tahun 1944 tidak dicantumkan mengenai sejauh mana batas kedaulatan negara di ruang udara. Demikian juga dalam Space Treay Tahun 1967 tidak dicantumkan mengenai batas dimulainya ruang angkasa. padahal penetapan batas antara ruang udara dan ruang angkasa ini sangat penting. Hal ini berguna untuk mengetahui sejauh mana suatu negara dapat menjalankan kedaulatannya atas ruang udara yang menjadi teritory-nya.

Dalam perkembangan hukum internasional klasik, suatu Negara dapat menjalankan kedaulatannya di ruang udara, tetapi kedaulatannya tidak dapat berlaku di ruang angkasa. karena ruang angkasa adalah milik seluruh umat manusia dan penggunaanya untuk kepentingan seluruh umat manusia. Tidak ada satu negara-pun yang berdaulat atas ruang angkasa. Pada ruang udara dan ruang angkasa juga berlaku prinsip yang berbeda, yaitu ketidakbebasan untuk memanfaatkan ruang udara dan kebebasan untuk memanfaatkan ruang angkasa. Namun dalam hukum Internasional modern konsep ini tidak dapat dianut lagi, karena pada batasan tertentu negara masih mempunyai kedaulatan di ruang angkasa.

Melihat kenyataan tersebut, maka penting untuk menetapkan batas antara ruang udara dan ruang angkasa. Namun karena belum ada aturan yang menetapkan batas tersebut, maka untuk mengkaji hal tersebut didasarkan pada teori-teori yang berkembang. Salah satu batas yang 
mungkin dapat diterima adalah yang terletak antara ketinggian maksimum di mana pesawat udara biasa masih bisa beroperasi, yaitu yang bergantung pada reaksi udara untuk gaya angkat dan pengemudian dan titik paling rendah di mana satelit bumi masih bisa mengorbit tanpa dihambat oleh pergeseran dengan udara, yaitu antara 40 dan 90 mil di atas permukaan bumi. $^{4}$ Selain pendapat tersebut, ada beberapa teori yang dikemukakan mengenai batas antara ruang udara dan ruang angkasa. Antara lain sebagai berikut : ${ }^{5}$

1. Garis batas berdasarkan konsepsi atmosfir. Alasan untuk teori ini adalah bahwa dalam teks Konvensi Chicago Tahun 1944 dalam bahsa Perancis dipergunakan kata "espace atmospherique" sebagai sinonim kata "airspace". Atmosfir adalah lapisan udara di atas bumi yang berisi bermacam gas seperti $\mathrm{N} 2, \quad \mathrm{O} 2, \mathrm{H} 2$ dan lain-lain, dan mempunyai kepadatan dan tekanan tertentu. Akan tetapi batas demikian tidak mungkin konkrit, karena bagaimanapun juga pada ketinggian beberapa ratus kilometer pun masih terdapat unsur-unsur atmosfir;

2. Garis batas ditentukan berdasarkan pembagian atmosfir dalam empat lapisan yaitu troposfir, stratosfir, mesosfir, dan ionosfir. Ruang udara hanya meliputi stratosfir karena pesawat udara tidak bisa melebihi stratosfir;

\footnotetext{
4 Suherman E, Wilayah Udara dan Wilayah Dirgantara, Bandung: Alumni, 1984, hlm 15

${ }^{5}$ Suherman E, ibid
}

3. Teori Konvensi Chicago Tahun 1944 atau teori International Civil Aviation Organitation (ICAO) berdasarkan maksimum ketinggian yang dapat dipakai pesawat udara biasa, yang oleh ICAO didefinisikan sebagai "setiap alat yang mendapat gaya angkat aerodinamis dari reaksi udara";

4. Batas berdasarkan Garis Von Karmen, berdasarkan titik dimana gaya angkat aerodinamis dikalahkan oleh gaya sentrifugal, yaitu pada ketinggian kira-kira 90 $\mathrm{km}$. Suatu teori yang sederhana buyinya akan tetapi tidak praktis karena pada ketinggian 90 km gaya angkat aerodinamisnya sudah sedemikian kecilnya sehingga tidak dapat lagi dimanfaatkan oleh pesawat udara biasa;

5. Batas antara ruang udara dan ruang angkasa ditetapkan berdasarkan titik terendah dari suatu satelit buatan (perigee);

6. Batas berdasarkan titik di mana sudah tidak ada lagi gaya tarik bumi. Benda yang dilepaskan pada ketinggian ini tidak akan jatuh ke bumi akan tetapi akan melayang di angkasa. Teori ini didasarkan pada asumsi bahwa demi keamanan suatu negara ruang dibawah garis ini masih bisa dipergunakan untuk melakukan pengeboman atas wilayah negara lain;

7. Batas ditentukan berdasarkan kemampuan negara dibawahnya untuk secara efektif melakukan kekuasaannya. Suatu teori yang bisa disebut teori kekuatan dan berakibat bahwa batas antara ruang 
udara dan ruang angkasa akan berbeda untuk tiap negara;

8. Teori zona membagi ruang udara menjadi ruang udara yang tunduk pada kedaulatan suatu negara, berdasarkan kemampuan terbang suatu pesawat udara biasa atau dengan suatu cara pembatasan lain, suatu daerah lintas (contiguous zone) yang dapat dilalui dengan bebas oleh pesawat udara non militer dan di atas kedua zona tersebut terdapat suatu ruang yang bebas;

9. Batas yang ditentukan secara arbiter dengan suatu perjanjian internasional;

10. Suatu kombinasi antara teori-teori di atas.

Teori-teori diatas berusaha memberikan batasan yang jelas di mana batas kedaulatan suatu negara atas ruang udaranya. Tapi ada juga teori yang mengatakan bahwa kedaulatan negara atas ruang udara itu tidak terbatas. Hal inilah yang dikemukakan oleh shawcross dan Beamont. Mereka menafsirkan kata-kata "complete and exclusive souvereignty" yang tercantum dalam Konvensi Chicago Tahun 1944 sebagai "without limit of height". Suatu resiko dari teori wilayah udara tanpa batas adalah bahwa teori tersebut dapat menimbulkan reaksi berupa doktrin penguasaan efektif. ${ }^{6}$ Doktrin yang dianut oleh Hans Kelsen ini mengatakan bahwa :

“....seluruh ruang di atas dan di bawah teritorial negara (sebagai bagian dari permukaan bumi) termasuk teritorial negara tanpa memperhatikan tingkat

\footnotetext{
${ }^{6}$ Suherman E, Ibid, hlm 3-4
}

pengawasannya yang efektif ... beralasan bahwa suatu negara dapat menegakan ketentuan-ketentuan Konvensi ini atau tata hukum nasionalnya sendiri terhadap pesawat neegara lain hanya di dalam bagian ruang angkasa dari jangkauan pengawasan efektifnya. Validitas suatu tata hukum tidak dapat menjangkau melampaui ruang lingkup ini.... sangat mungkin bahwa ruang angkasa dan juga ruang bawah tanah yang berada di luar penguasaan efektif "negara teritorial" itu berkarakter bukan wilayah milik negara manapun. Namun demikian, tampak bahwa, menurut hukum internasional umum, negara-negara lain tidak mempunyai hak untuk menduduki ruang ini meskipun mereka memiliki kemampuan teknis untuk berbuat demikian. Satu-satunya cara untuk menentukan sifat dari bagian-bagian ruang ini menurut prinsip efektivitas adalah menerima suatu hak eksklusif "negara teritorial" untuk menduduki, yakni, untuk memperluas menurut kemajuan peralatan-peralatan tekniknya dan efektivitas tata hukumnya kepada bagian-bagian ruang angkasa dan bawah tanah yang sebelumnya berada di luar penguasaan efektivitasnya."7

Jadi menurut doktrin ini, kedaulatan suatu negara atas ruang udaranya sematamata ditentukan oleh kemampuan teknik yang dimiliki oleh negara tersebut untuk menjalankan kedaulatannya dalam ruang lingkup yang bisa dijangkaunya. Diluar

\footnotetext{
7 Kelsen H, Teori Umum Hukum dan Negara, Jakarta: Bee Media Indonesia, 2007, hlm 267-268
} 
dari kemampuan teknik untuk menjangkaunya maka itu merupakan ruang yang bisa dimanfaatkan oleh negara lain. Penerapan doktrin ini jelas akan menimbulkan masalah yang sangat serius menyangkut kedaulatan negara di ruang udara, karena adanya perbedaan kemampuan teknik yang dimiliki oleh negara-negara di dunia ini. Negara yang mempunyai kemampuan teknik lebih maju akan memiliki ruang lingkup kedaulatan yang lebih luas dibandingkan dengan negara yang kemampuan tekniknya rendah.

Melihat banyaknya teori tentang batas antara ruang udara dan ruang angkasa maka akan sangat sulit untuk menetapkan batas yang jelas antara ruang udara dan ruang angkasa sehingga akan sukar juga untuk menentukan batas berakhirnya kedaulatan negara di ruang udara, namun yang sangat penting untuk diperhatikan dalam hal ini adalah kepentingan negara kolong (subjacent state) harus tetap diprioritaskan. Oleh karena itu dalam hal penerbangan yang dilakukan oleh pesawat F-18 Hornet harus memperhatikan kepentigan dari Indonesia sebagai negara kolong, yang secara hukum internasional diakui kedaulatannya atas ruang udara yang ada di atas wilayahnya tersebut.

Kepentingan Indonesia harus diprioritaskan karena apabila terjadi kecelakaan akibat penerbangan tanpa izin dan manuver yang dilakukan oleh pesawat F-18 Hornet dalam jalur penerbangan sipil tersebut maka Indonesia sebagai negara kolong berada pada posisi yang dirugikan. Pertama jelas kedaulatan Indonesia dilanggar karena penerbangan itu dilakukan tanpa izin dari Indonesia sebagai negara yang berdaulat atas ruang udara yang dilalui oleh pesawat F-18 hornet. Selanjutnya manuver yang dilakukan oleh pesawat F-18 Hornet membahayakan keamanan navigasi penerbangan pesawat sipil yang melintas dalam jalur tersebut, selain itu Pesawat F18 hornet menunjukan sikap yang bermusuhan terhadap pesawat F-16 Indonesia yang pada saat itu ditugasi untuk melakukan identifikasi. Dengan demikian, Apa yang telah dilakukan oleh pesawat F-18 Hornet tersebut jelas-jelas menenjukan bahwa kepentingan Indonesia sebagai negara kolong sama sekali tidak diperhatikan.

Berdasarkan teori-teori yang dipaparkan di atas maka juga dapat diketahui bahwa penerbangan pesawat F18 Hornet yang dilakukan pada ketinggian 15.000 kaki atau 4,752 $\mathrm{km}$ masih berada dalam batas dimana suatu negara masih mempunyai kedaulatan atas ruang udaranya. Dalam kasus ini adalah wilayah ruang udara yang menjadi kedaulatan Indonesia karena masih berada dalam wilayah ruang udara Indonesia, maka penerbangan F-18 Hornet harus dilakukan dengan izin dari pemerintah Indonesia.

Dalam pasal 1 Konvensi Chicago Tahun 1944 juga dinyatakan bahwa setiap negara memiliki kedaulatan yang lengkap dan eksklusif terhadap ruang udara di atas wilayahnya. Konsekuensi prinsip kedaulatan ini adalah tidak ada pesawat udara yang terbang atau ke atau melalui ruang udara nasional negara anggota tanpa memperoleh izin terlebih dahulu berapapun tinggi atau rendahnya pesawat udara melakukan penerbangan. Pengakuan kedaulatan di udara tidak terbatas pada negara anggota saja, melainkan juga berlaku terhadap bukan negara anggota 
Konvensi Chicago Tahun 1944. Hal ini jelas dengan adanya istilah every state. Oleh karena itu, pesawat F-18 Hornet milik angkatan laut Amerika Serikat wajib melapor kepada pemerintah Indonesia tentang keinginan untuk melakukan penerbangan pesawat dan melakukan latihan di ruang udara milik Negara Indonesia. Sekalipun pihak angkatan laut Amerika Serikat telah melaporkan dan meminta izin kepada pemerintah Indonesia, namun mereka belum boleh melakukan penerbangan sebelum ada persetujuan dari pemerintah Indonesia untuk memperbolehkan mereka melakukan penerbangan.

Selanjutnya, dalam Pasal 6 konvensi Chicago telah ditegaskan bahwa tidak ada pesawat udara negara lain yang dapat terbang di ruang udara negara lainnya, kecuali telah memperoleh izin terlebih dahulu dari negara yang bersangkutan. Oleh karena itu, sebelum melakukan penerbangan, F-18 Hornet harus terlebih dahulu meminta izin kepeda pemerintah Indonesia. Dalam keterangan yang diberikan oleh duta besar Amerika Serikat untuk Indonesia dikatakan bahwa pihak Amerika telah melakukan notifikasi sebelum melakukan penerbangan, tapi karena notifikasi tersebut belum ditanggapi oleh pemerintah Indonesia, apakah memberikan izin penerbangan atau tidak, maka pesawat F-18 Hornet dilarang terbang di atas ruang udara Indonesia. Hal ini yang tidak dilakukan oleh F-18 Hornet dan dengan ini menunjukan secara jelas bahwa kedaulatan Indonesia telah dilanggar oleh Amerika Serikat.

Notifikasi merupakan pemberitahuan, oleh karena itu butuh konfirmasi dari pemerintah Indonesia sebagai pemegan kedaulatan untuk memberikan izin atau tidak. Kalau sudah ada izin dari pemerintah Indonesia terhadap konfirmasi tersebut barulah pesawat F-18 Hornet dapat melakukan penerbangan. Sepanjang izin belum diberikan maka penerbangan itu tidak boleh dilakukan.

\section{Pengklasifikasian Pesawat Udara}

Berkaitan dengan kedaulatan negara di ruang udara maka perlu juga dilihat mengenai pengklasifikasian pesawat udara. Hal ini penting karena berkaitan dengan tindakan apa saja yang boleh dilakukan dan tidak boleh dilakukan di atas ruang udara yang berada di bawah kedaulatan suatu negara. Fauchille dalam tulisannya kepada institut de Droit Intrnational pada tahun 1902 mengklasifikasikan alat-alat penerbangan dalam pesawat udara publik dan pesawat udara privat. Tetapi kemudian pada tahun 1910 dalam pertemuan antar negaranegara mengenai penerbangan di Paris, ia mengajukan klasifikasi yang lebih luas lagi, yakni pesawat udara publik dibaginya lagi dalam pesawat udara militer dan peswat udara sipil. $^{8}$ Klasifikasi semacam ini telah dilakukan pula oleh para ahli-ahli lainnya sampai akhirnya kemudian dicantumkan di dalam pasal 30 Konvensi Paris 1919 yang mengatakan bahwa : ${ }^{9}$

"the following shall be deemed to be state aircraft.

a. Military aircraft

b. Aircraft exclusively employed in state service, such as post, customs, police.

\footnotetext{
8 Abdurasyid. P, Kedaulatan Negara Di Ruang Udara, Jakarta: Pusat penelitian Hukum Angkasa, 1972, hlm. 133.

${ }^{9}$ Abdurasyid. P, Ibid
} 
c. Every other aircraft shall be deemed to be privat aircraft

Dalam Konvensi Chicago terdapat pula pasal yang mengadakan klasifikasi pesawat udara. Pasal 3 Konvensi Chicago berbunyi :

"civil and state aircraft.

a. This convention shall be applicable only to civil aircraft, and shall not applicable to state aircraft.

b. Aircraft used in military, customs and police servies shall be deemed to be state aircraft.

c. No state aircraft of contracting state shall fly over the territory of another state or land thereon without authorization by special agreement or otherwise, and in accordance with the terms thereof.

$d$. The contracting state undertake, when issuing regulations for their state aircraft, that they will have due regard for the safety of navigation of civil aircraft.

Dari pasal tersebut dapat dilihat bahwa pesawat udara diklasifikasikan menjadi dua, yaitu pesawat udara sipil (civil Aircraft) dan pesawat udara negara (state aircraft). Pesawat udara Negara mencakup pesawat udara yang digunakan untuk militer, polisi dan bea cukai. Antara kedua jenis pesawat udara ini terdapat perbedaan perlakuan ketika melakukan penerbangan di ruang udara. Berdasarkan Pasal 3 butir b, Pesawat F-18 Hornet diklasifikasikan sebagai pesawat udara negara, karena merupakan pesawat udara yang melakukan pelayanan militer. Suatu pesawat udara disebut pesawat udara negara bukan karena kepemilikannya, tetapi karena kewenangannya. Misalkan pesawat udara
Garuda dan Merpati Airlines merupakan pesawat udara milik pemerintah, tapi tidak diklasifikasikan sebagai pesawat udara negara. Pesawat tersebut merupakan pesawat udara sipil, karena kewenangannya tidak mencakup kriteria yang ditetapkan dalam Pasal 3 butir b. Oleh karena merupakan pesawat udara negara, maka terhadap pesawat F-18 Hornet berlaku batasan tertentu ketika melakukan penerbangan di ruang udara.

Merujuk pada Pasal 3 butir d, pesawat udara negara dilarang untuk mengganggu keamanan navigasi penerbangan sipil. Namun secara jelas dapat dilihat dalam kasus posisi yang telah dipaparkan sebelumnya bahwa pesawat F-18 Hornet telah melakukan yang menggangu keamanan navigasi penerbangan sipil. Manuver tersebut dilakukan dalam jalur penerbangan sipil dan hal tersebut dilihat oleh pilot Boeing 737-200 Bouraq. Hal tersebut secara jelas telah menunjukan pelanggaran atas Konvensi Chicago Tahun 1944.

\section{Tinjauan Berdasarkan Hukum Laut}

Undang-Undang Nomor 4 Perpu Tahun 1960 Tentang Perairan Indonesia menyatakan bahwa perairan Indonesia ialah laut wilayah (laut territorial) Indonesia beserta perairan pedalaman Indonesia. Dengan adanya ketentuan tersebut, Indonesia menganggap dirinya mempunyai hak kedaulatan atas segala perairan yang terletak di dalam batas-batas garis luar laut wilayah, atas wilayah daratan dan ruang udara di atasnya. ${ }^{10}$ Namun karena Indonesia merupakan Negara kepulauan maka wilayah-wilayah daratan (pulau-pulau) yang terpisah oleh

\footnotetext{
${ }^{10}$ Abdurasyid P, Ibid, hlm 136
} 
lautan, meskipun merupakan bagian dari wilayah Indonesia tapi tidak dipandang sebagai satu kesatuan tapi berdiri sendiri. sehingga mengakibatkan kedaulatan Indonesia di ruang udara akan terpecahpecah menurut bentuk dan banyaknya pulau yang ada. Tetapi dengan diakomodirnya doktrin tentang wawasan nusantara dalam Konvensi Hukum Laut Tahun 1982 membuat wilayah Indonesia yang terdiri dari pulau-pulau ini tidak lagi terpecah-terpecah tapi dipandang sebagai satu kesatuan. Karena berdaulat atas wilayah perairan dan daratan yang ada dan merupakan satu kesatuan, maka Indonesia juga memiliki kedaulatan atas ruang udara sejauh darat dan laut-nya,yang di tarik tegak lurus ke atas. Hal ini sesuai dengan dalil hukum romawi yang berbunyi cujus est solum, ejus est usque ad coelum yang artinya adalah "barangsiapa yang memiliki sebidang tanah dengan demikian juga memiliki segala-galanya yang berada di atas permukaan tanah tersebut sampai ke langit dan segala apa yang berada di dalam tanah".

Sebagai negara kepulauan yang memiliki kedaulatan atas wilayahnya, maka Indonesia dapat menetapkan alur laut kepulauan (archipelagic sealanes) dan rute penerbangan di atas alur laut tersebut. Kapal dan pesawat udara asing menikmati hak lintas alur laut kepulauan untuk transit dari bagian laut lepas atau Zona Ekonomi Eksklusif (ZEE) ke bagian lain dari laut lepas atau ZEE. Alur laut dan rute penerbangan tersebut ditetapkan dengan menarik garis poros. Kapal dan pesawat udara asing yang melakukan lintas transit melalui alur laut dan rute penerbangan tersebut tidak boleh berlayar atau terbang melampaui 25 mil laut dari sisi kiri kanan garis poros tersebut.

Sekalipun kapal dan pesawat udara asing menikmati hak lintas alur laut kepulauan melalui alur laut dan rute penerbangan tersebut, namun hal lain di bidang pelayaran dan penerbangan tidak boleh mengurangi kedaulatan negara kepulauan atas air dan ruang udara di atasnya, dasar laut dan tanah di bawahnya serta sumber kekayaan alam di dalamnya. Dengan demikian, hak lintas melalui rute penerbangan pada alur laut kepulauan yang diatur oleh konvensi ini hanya mencakup hak lintas melalui udara di atas alur laut tanpa mempengaruhi kedaulatan untuk mengatur penerbangan di atas wilayahnya sesuai dengan Konvensi Chicago Tahun 1944 Tentang Penerbangan Sipil atau kedaulatan negara kepulauan atas wilayah udara lainnya di atas perairan kepulauan. ${ }^{11}$

Pasal 2 Konvensi Hukum Laut Tahun 1982 menyatakan bahwa :

1. Kedaulatan suatu negara pantai, selain wilayah daratan dan perairan pedalamannya dan, dalam hal suatu negara kepulauan, perairan kepulauannya, meliputi pula suatu jalur laut yang berbatasan dengannya dinamakan laut territorial.

2. Kedaulatan ini meliputi ruang udara di atas laut territorial serta dasar laut dan tanah di bawahnya.

Dalam Pasal 49, ditetapkan bahwa lingkup kedaulatan suatu negara sebagai berikut :

${ }^{11}$ Badan Pembinaan Hukum Nasional Departemen Kehakiman Dan HAM RI, Analisis dan Evaluasi Hukum Tentang Perjanjian Internasional Di Bidang Kewilayahan, Jakarta, 2001, hlm. 26 
1. Kedaulatan suatu negara kepulauan meliputi perairan yang ditutup oleh garis pangkal kepulauan, yang ditarik sesuai dengan ketentuan pasal 47, disebut sebagai perairan kepulauan, tanpa memperhatikan kedalaman atau jaraknya dari pantai.

2. Kedaulatan ini meliputi ruang udara di atas perairan kepulauan, juga dasar laut dan tanah di bawahnya, dan sumber kekayaan yang terkandung di dalamnya.

Dari pasal-pasal di atas tersebut dapat dilihat bahwa kedaulatan negara pantai tidak hanya atas laut teritorial, perairan pedalaman serta perairan kepulauan saja tapi juga meliputi ruang udara yang berada di atasnya. Dalam kovensi ini juga ditetapkan bahwa perairan pedalaman merupakan bagian dari wilayah negara pantai dan negara pantai mempunyai kedaulatan atasnya. Oleh Bouve juga dikatakan bahwa pihak yang hadir dalam Konvensi Paris dengan sadar memberikan pengakuannya bahwa setiap negara mempunyai kedaulatan yang lengkap dan eksklusif terhadap ruang udara dan perairan teritorialnya. ${ }^{12}$

Ditinjau dari konvensi hukum laut tahun 1982, penerbangan pesawat F-18 Hornet jelas telah melanggar wilayah Indonesia. Laut Jawa yang dilalui oleh kapal induk USS Carl Vinson merupakan perairan pedalaman dan bagian dari wilayah Indonesia. Oleh karena itu, ruang udara yang berada di atas perairan

\footnotetext{
12 Likadja. F, Masalah lintas Di Ruang Udara,
} Kupang: Binacipta, 1987, hlm.27 pedalaman itu juga merupakan wilayah Indonesia.

Masalahnya adalah Amerika Serikat tidak meratifikasi konvensi hukum laut tahun 1982, sehingga mereka menganggap perairan Laut Jawa yang dilaluinya merupakan perairan internasional dan ruang udara yang ada di atasnya merupakan ruang udara bebas yang tidak tunduk pada kedaulatan Indonesia. Meskipun Amerika Serikat tidak meratifikasi konvensi ini namun aturan yang telah ditetapkan dalam konvensi ini diadopsi dari praktek hukum kebiasaan yang diterima oleh negara-negara, oleh karena itu Amerika tidak bisa menjadikannya sebagai dasar pembenaran terhadap tindakan yang dilakukan pesawat F-18 Hornet.

Celah hukum yang ada inilah yang coba dimanfaatkan oleh Amerika Serikat dalam kasus ini. Namun meskipun tidak meratifikasi Kovensi Hukum Laut Tahun 1982, Amerika harus tetap menghormati kedaulatan Indonesia yang diakui dalam konvensi ini. Tindakan Amerika yang seperti ini menunjukan adanya tindakan tidak menghargai kedaulatan Indonesia dan tidak menghormati aturan internasional.

\section{Kekuatan Militer Indonesia dan Amerika Serikat}

Pasal 1 Konvensi Chicago menetapkan bahwa kedaulatan yang dimiliki setiap negara atas ruang udara-nya bersifat mutlak dan eksklusif. Kedaulatan ini wajib dihormati oleh setiap negara yang lain, baik itu negara yang merupakan anggota Konvensi ataupun bukan. Secara hukum, pengakuan kedaulatan negara atas ruang udara telah ditetapkan. Namun tidaklah cukup hanya dengan pengakuan secara 
hukum saja. Supaya kedaulatan tersebut tetap terjaga dan dihormati oleh negara lain, maka suatu negara harus mempunyai kekuatan untuk menjaga kedaulatan wilayahnya tersebut. Apalagi dalam hukum internasional, penegakan suatu aturan hukum internasonal tidak dapat dipaksakan seperti dalam hukum nasional, karena tidak ada satu negara-pun yang posisinya berada di bawah negara lain dan tidak ada organisasi lain yang berada di atas negara. Setiap negara mempunyai posisi yang setara. Oleh karena itu suatu negara harus bisa menjaga kedaulatan wilayahnya dengan kekuatannya sendiri.

Sebagai subyek hukum internasional, negara memang dituntut untuk saling menghormati satu dan lainnya, karena semuanya merupakan negara yang berdaulat. Namun tidak jarang negara yang satu menunjukan sikap yang tidak menghormati kedaulatan negara lain. Salah satu tindakan yang dilakukan misalnya adalah pelanggaran kedaulatan wilayah. Hal inilah yang telah dilakukan oleh pesawat F-18 hornet milik Amerika serikat, yang melanggar kedaulatan negara Indonesia atas ruang udara-nya.

Ada berbagai macam faktor yang dapat melatar belakangi tindakan tersebut, tapi menurut hemat penulis, dalam kasus ini, selain adanya celah hukum (tidak diratifikasinya Konvensi Hukum Laut Tahun 1982), faktor kekuatan militer merupakan salah satu alasan yang cukup kuat sehingga terjadinya pelanggaran tersebut. Berdasarkan data kekuatan militer negara-negara yang dirilis situs Globalfirepower.com, Amerika Serikat berada pada urutan pertama negara yang memiliki kekuatan militer terkuat.
Sedangkan Indonesia berada pada urutan ke tiga belas. Untuk lebih jelasnya maka dapat dilihat pada data dibawah ini. 
Tabel 1. Perbandingan kekuatan militer Amerika serikat Dan Indonesia

\begin{tabular}{|c|c|c|c|}
\hline No & Detail & United States Of America & Indonesia \\
\hline \multicolumn{4}{|c|}{ PERSONEL } \\
\hline 1 & Active Military Personnel & 1.385 .122 & 316.000 \\
\hline 2 & Active Military Reserve & 1.458 .500 & 400.000 \\
\hline 3 & Active Paramilitary Units & 453.000 & 207.000 \\
\hline \multicolumn{4}{|c|}{$A R M Y$} \\
\hline 4 & Total Land-Based Weapons & 29.920 & 2.122 \\
\hline 5 & Towed Artillery & 5.178 & 293 \\
\hline \multicolumn{4}{|c|}{$N A V Y$} \\
\hline 6 & Total Navy Ships & 1.559 & 111 \\
\hline 7 & Merchant Marine Strength & 422 & 971 \\
\hline 8 & Major Ports and Harbors & 10 & 10 \\
\hline 9 & Aircraft Carriers & 12 & 0 \\
\hline 10 & Destroyers & 50 & 0 \\
\hline 11 & Submarines & 75 & 2 \\
\hline 12 & Frigates & 92 & 15 \\
\hline 13 & Patrol \& Coastal Craft & 100 & 24 \\
\hline 14 & Mine Warfare Craft & 28 & 12 \\
\hline 15 & Amphibious Craft & 38 & 26 \\
\hline \multicolumn{4}{|c|}{ AIR FORCE } \\
\hline 16 & Total Aircraft & 18.169 & 313 \\
\hline 17 & Helicopters & 4.593 & 194 \\
\hline 18 & Serviceable Airports & 14.947 & 652 \\
\hline
\end{tabular}

Sumber : http://www.Globalfirepower.com, 2008

Dari data di atas jelas terlihat adanya perbedaan kekuatan militer yang sangat besar antara Amerika Serikat dan Indonesia. Di setiap segi yang ada, baik itu dari segi personel, angkatan darat, angkatan laut dan angkatan udara, Amerika Serikat selalu unggul atas Indonesia. Dengan kekuatan tempur sebesar ini tidaklah cukup untuk mengatakan bahwa hal ini menjadi dasar Amerika Serikat melanggar kedaulatan Wilayah Indonesia.

Selain memiliki kekuatan tempur yang jauh mengungguli Indonesia, perlu juga diketahui bahwa Amerika Serikat juga menganut doktrin Control Theory yang dipelopori oleh Cooper. Teori ini mengatakan bahwa kebijakan (policy) Amerika ditentukan oleh kekuatan fisik (tempur) dan ilmiah (penguasaan ruang angkasa). Inti dari teori ini adalah selama suatu negara mempunyai kemampuan atau kekuatan, maka batas negara tersebut dapat berada di mana saja. Karena sangat bergantung pada kekuatan tempurnya ini maka Amerika Serikat mengeluarkan biaya yang sangat besar untuk anggaran pertahanannya. Pada tahun 2009 anggaran pertahanan Amerika Serikat mencapai \$515.400.000.000, jauh lebih tinggi dari Indonesia yang menganggarkan $\$ 4.740 .000 .000$ untuk anggaran 
pertahanan pada tahun 2008. ${ }^{13}$ Hingga tahun 2007 Amerika telah menghabiskan 645 Miliar dolar untuk biaya perang Irak dan Afghanistan. Biaya operasi, atau "tingkat habisnya uang" bulanan, dalam perang ini terus menerus naik sejak 2003dari 4,4 miliar dolar menjadi 12 miliar dolar dan diperkirakan menjadi 16 miliar dolar pada tahun 2008. ${ }^{14}$

Berdasarkan teori yang dianut ini maka dapat dilihat bahwa Amerika Serikat sangat serius dalam mengembangkan kekuatan militernya. Hal ini tercermin dari besarnya jumlah dana pertahanan yang dianggarkan dan biaya jumlah perang yang telah dikeluarkan selama perang Irak dan Afghanistan. Berdasarkan hal tersebut maka dapat dilihat bahwa besarnya kekuatan militer Amerika Serikat sangat berpengaruh dalam hal terjadi pelanggaran kedaulatan wilayah ruang udara Indonesia yang dilakukan oleh Pesawat F-18 Hornet milik Amerika serikat.

Atas pelanggaran yang dilakukan oleh pesawat F-18 Hornet ini, maka pemerintah Indonesia seharusnya memberikan tanggapan yang keras. Memasuki ruang udara (air space) di atas wilayah suatu negara tanpa ijin terlebih dahulu adalah suatu pelanggaran atau kejahatan(aerialin struction)

yang bisa menjadi alasan dilakukan tindakan pencegatan (interception). Hal ini dapat dilakukan dengan melayangkan nota protes kepada pemerintah Amerika Serikat. Jika pemerintah menghendaki, maka pemerintah dapat saja melakukan reaksi yang lebih keras dengan menembak

\footnotetext{
${ }^{13}$ www.Globalfirepower.com

${ }^{14}$ Stiglitz E. Joseph dan Bilmes J. Linda, Perang Tiga Triliun Dolar, Bencana Ekonomi Dibalik Invansi Amerika Ke Irak, Bandung: Mizan, 2009, hlm 63
}

jatuh pesawat tersebut karena dapat dianggap melanggar kedaulatan Indonesia. Sebagai perbandingan kita dapat melihat pesawat Korean Airlines yang pernah dicurigai Rusia karena masuk ke Wilayahnya tanpa izin akhirnya ditembak jatuh dengan meriam sehingga menewaskan 100 orang. Contoh lainnya adalah ketika jet J-8 angkatan udara Cina yang perlu menabrak pesawat elektronik EP-3E Aries milik Amerika Serikat, karena dinilai terlalu berlebihan dan melakukan pengintaian. Pada Tahun 1960an, pesawat udara mata-mata, U2, milik Amerika Serikat yang terbang di atas di atas wilayah Uni Soviet dengan ketigian di atas 76.000 kaki, ditembak oleh Uni Soviet dan penerbangnya diadili oleh Uni Soviet. ${ }^{15}$

Solusi kedua yang dapat diambil adalah dengan mengajukan masalah ini ke pengadilan internasional. Namun meskipun masalah ini sampai ke pengadilan internasional sekalipun, jalan keluar yang akan diambil tidak akan mudah karena masing-masing pihak menggunakan dasar hukum yang berbeda. Indonesia dapat mengajukan tuntutan ke pengadilan internasional dengan menggunakan dua dasar hukum. Yang pertama dengan menggunakan Konvensi Chicago Tahun 1944. berdasarkan konvensi ini, F-18 hornet Amerika Serikat telah melanggar telah melanggar pasal 1, pasal dan pasal 3 huruf $\mathrm{c}$ dan d, serta pasal 6. Dasar hukum kedua yang dapat digunakan adalah Konvensi Hukum Laut Tahun 1982. Ditinjau dari Konvensi ini, Peswat F-18 Hornet telah melanggar Pasal 2 dan Pasal 49. Namun permasalahan hukum yang timbul di sini adalah Amerika

\footnotetext{
${ }^{15}$ Martono. H. K, Ibid, hlm 638
} 
Serikat tidak meratifikasi Konven Hukum Laut Tahun 1982, sehingga kalau Indonesia menuntut dengan menggunakan dasar hukum ini maka tidak banyak gunanya. Jadi alternatif terbaik adalah dengan menuntut Amerika Serikat berdasarkan Konvensi Chicago Tahun 1944 karena Konvensi ini sama-sama diratifikasi oleh Amerika Serikat dan Indonesia.

\section{PENUTUP}

Berdasarkan analisis di atas maka dapat dilihat bahwa Pesawat F-18 Hornet milik Amerika serikat secara jelas telah melanggar kedaulatan wilayah Indonesia, dengan melakukan penerbangan tanpa izin dari pemerintah Indonesia sebagai pemegang kedaulatan dan pesawat F-18 Hornet yang merupakan pesawat udara negara juga melakukan manuver dalam jalur penerbangan sipil yang dapat membahayakan keamanan navigasi pesawat udara sipil. Tindakan ini merupakan pelanggaran baik terhadap ketentuan-ketentuan yang dimuat dalam konvensi Chicago Tahun 1944 maupun konvensi Hukum Laut Tahun 1982, yang mengakui adanya kedaulatan dari Negara kolong terhadap ruang udara diatas wilayah teritorialnya. Kekuatan militer Amerika serikat yang jauh mengungguli Indonesia sangat mempengaruhi tindakan Pelanggaran kedaulatan wilayah ini. Hal ini juga dipengaruhi oleh doktrin Control Theory yang dianut oleh Amerika Serikat dan lebih besarnya kekuatan militer yang dimilki oleh Amerika serikat jika dibandingkan dengan Indonesia.

\section{DAFTAR PUSTAKA}

\section{Buku}

Abdurasyid Priyatna, Kedaulatan Negara Di Ruang Udara, Jakarta: Pusat penelitian hukum angkasa, 1972

Abdurasyid Priyatna, Hukum Antariksa

Nasional (Penempatan Urgensinya),

Jakarta: Rajawali, 1989

Badan Pembinaan Hukum Nasional

Departemen Kehakiman Dan HAM

RI, Analisis dan Evaluasi Hukum

Tentang Perjanjian Internasional Di

Bidang Kewilayahan. Jakarta, 2001

Badan Pembinaan Hukum Nasional

Departemen Kehakiman RI,

Perkembangan Pembangunan Hukum

Nasional Tentang Hukum Dirgantara. Jakarta, 1996

Kantaatmadja Mieke Komar, Berbagai

Masalah Hukum Udara Dan Angkasa,

Bandung: Remadja Karya, 1988

Kantaatmadja Mieke Komar, Lembaga Jaminan Kebendaan Pesawat Udara Indonesia Ditinjau Dari Hukum Udara. Bandung: Alumni, 1989

Kelsen H, Teori Umum Hukum dan Negara, Jakarta: Bee Media Indonesia, 2007

Likadja Frans, Masalah lintas Di Ruang udara, Kupang: Binacipta, 1987

Martono H. K, Pengantar Hukum Udara Nasional Dan Internasional, Bagian Pertama, Jakarta: Raja Grafindo, 2007

Muhammad Abdulkadir, Hukum dan Penelitian Hukum, Bandung: Citra Aditya Bakti, 2004

Nazir Moh, Metode Penelitian. Jakarta: Gahlia Indonesia, 1988

Parthiana I Wayan, Pengantar Hukum Internasional, Bandung: Mandar Maju, 2003 
Songa. W. W, Hukum Perjanjian Internasional. Kupang, 2008

Starke J. G, Pengantar Hukum Internasional, Edisi Kesepuluh, 1, Jakarta: Sinar Grafika, 2004

Stiglitz E. Joseph dan Bilmes J. Linda, Perang Tiga Triliun Dolar, Bencana Ekonomi Di Balik Invasi Amerika Ke Irak, Bandung: Mizan, 2009

Suherman. E, Wilayah Udara dan Wilayah Dirgantara, Bandung: Alumni, 1984

Thontowi Jawahir. dan Iskandar Pranoto, Hukum Internasional Kontemporer, Bandung: Refika Aditama, 2006;

Wiradipradja E. Saefullah, Hukum Transportasi Udara, Bandung: Kiblat Buku Utama, 2008.

\section{Perjanjian Internasional}

Konvensi Chicago Tahun 1944 Tentang Penerbangan Sipil Internasional

Konvensi Hukum Laut Tahun 1982

\section{Internet}

http://www.globalfirepower.com

http://www.angkasaonline.com/13/11/hori zon/horizon1.htm

\section{Kamus}

Martono H. K., 2007, Kamus Hukum dan Regulasi penerbangan; edisi pertama, Jakarta: Radja Grafindo 